NINA WHITE

\title{
JUDICIAL INFRINGEMENT OF THE RIGHT TO INTERNET ACCESS BY THE IMPOSITION OF SPECIAL SENTENCING CONDITIONS
}

\author{
Submitted for the LLB (Honours) Degree
}

Faculty of Law

Victoria University of Wellington

2014 


\section{Abstract}

Section 14 of the Bill of Rights Act extends to protect internet access within New Zealand as a means of expression. Judicial restriction of internet access via the imposition of special conditions during sentencing is therefore an infringement of $\mathrm{s} 14$. This interpretation of $\mathrm{s}$ 14 is consistent with its purpose, legislative history, and the broad approach afforded to human rights generally, as well as international case law and statutes. Any imposition of special conditions restricting internet access must be a demonstrably justifiable limit per s 5 of the Bill of Rights Act to be legitimate. The practical considerations of such a technological limit also warrant judicial consideration before it is imposed. As yet, New Zealand has no explicit protection of internet access but growing acceptance of its importance indicates that reform or judicial acknowledgement are, or soon will be, required.

Bill of Rights Act, Freedom of Expression, Sentencing Conditions, Internet Access. 


\section{Table of Contents}

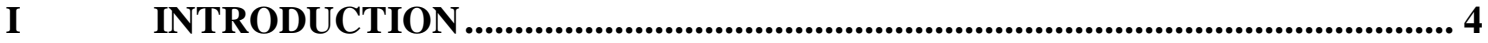

II PROTECTION OF INTERNET ACCESS IN NEW ZEALAND ....................... 6

A Freedom of Expression.....................................................6

1 Legislative Context ..............................................................................6

$2 \quad$ Purpose ....................................................................................................... 8

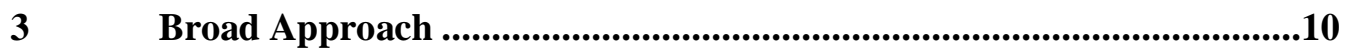

4 Conclusion on the Interpretation of $s$ 14 .............................................10

B Right or Freedom: Is there a positive obligation on the government?..................11

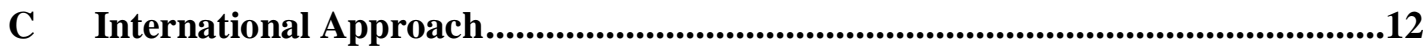

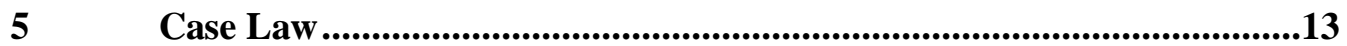

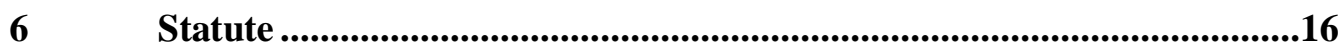

III STATE RESTRICTION OF INTERNET ACCESS ......................................17

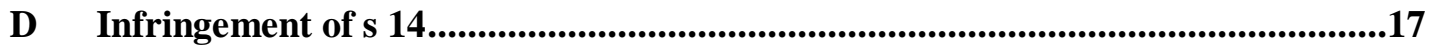

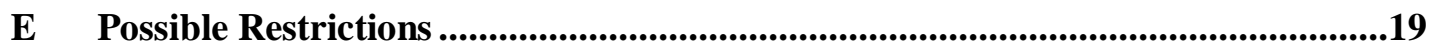

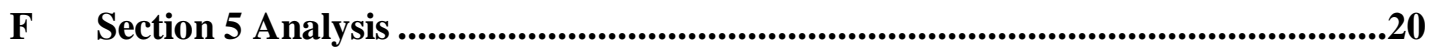

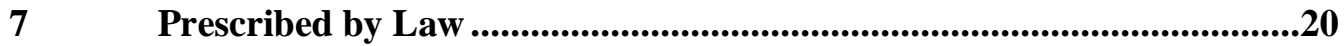

8 Demonstrably Justified in a Free and Democratic Society ....................21

9 Conclusion on s 5 ..................................................................................25

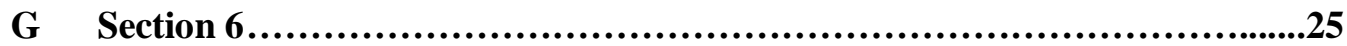

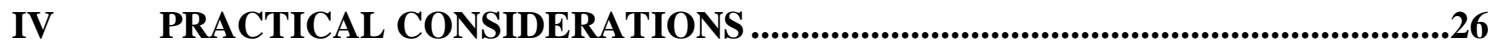

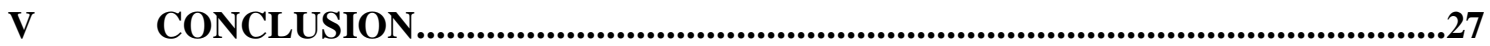

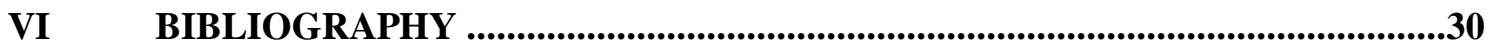




\section{Introduction}

The internet was conceived in the early 70s and since then it has grown exponentially. ${ }^{1}$ Today, nearly three billion people use the internet worldwide, including the overwhelming majority of the New Zealand population. ${ }^{2}$ It has proved an indispensable tool for communication and accessing information and as such, it has fundamentally changed the way people enjoy their right to freedom of expression. One may now seek, receive or impart information instantaneously and inexpensively to and from a global audience. ${ }^{3}$

In 2013 a study showed that 92 percent of New Zealanders used the internet ${ }^{4}$ while 80 percent of homes had an internet connection in $2012 .{ }^{5}$ The 2013 study also revealed that 73 percent of New Zealanders felt that the internet was important in their everyday lives. ${ }^{6}$ This is in line with a trend that has been growing over the last decade, and is set to continue with increasing emphasis being placed on it by all sectors, including government. ${ }^{7}$ The iGovt login system, an attempt to homogenise the login system of government websites, is one example of government acknowledgement of the importance of the internet as a communication tool, and a growing interface on which the public relies. ${ }^{8}$ The 2013 study showed that $81 \%$ of people view the internet as an important provider of information, which is a substantially higher proportion than any other information source. ${ }^{9}$

However, like all technological developments, the internet may be abused to cause harm to others. ${ }^{10}$ There have already been cases of internet-related crime ranging from terrorism

\footnotetext{
1 Barry Leiner and others "Brief History of the Internet" (accessed 2014) Internet Society www.internetsociety.org

${ }^{2}$ Internet Live Stats "Internet Users" (2014) Internet Live Stats www.internetlivestats.com

${ }^{3}$ United Nations General Assembly, Report of the Special Rapporteur on the promotion and protection of the right to freedom of opinion and expression, Frank La Rue (Human Rights Council, 17 $7^{\text {th }}$ session, 16 May 2011, A/HRC/17/27) at [19].

${ }^{4}$ C Crothers and others (2014) Internet Trends In New Zealand 2007-2013 Auckland, New Zealand: Institute of Culture, Discourse and Communication, Auckland University of Technology at 7.

${ }^{5}$ Geoff Bascand "Household Use of Information and Communication Technology: 2012" (2013) Statistics New Zealand at 1 .

${ }^{6}$ Crothers, above $\mathrm{n} 4$, at 9 .

${ }^{7}$ Crothers, above $\mathrm{n} 4$, at 2, 9.

${ }^{8}$ Susy Frankel, Deborah Ryder (eds) and Petra Butler Recalibrating Behaviour: Smarter Regulation in a Global World (LexisNexis, Wellington, 2013) at 519.

${ }^{9}$ Crothers, above n 4, at 10.

${ }^{10}$ La Rue, above n 3, at [69].
} 
to copyright infringement, with blackmail, privacy invasions and child pornography falling in between. ${ }^{11}$ Globally, courts have reacted to the use of the internet as an instrument in crime by restricting access to it as a special condition of sentencing for internet-related crimes. In New Zealand these conditions have thus far consisted mainly of minor restrictions, requiring supervision or permission to access the internet, but both the United Kingdom and the United States have had total restrictions of internet access judicially imposed. ${ }^{12}$ In the New Zealand cases where these conditions have been applied, there has been no discussion of their legality in regards to inconsistency with the New Zealand Bill of Rights Act 1990 (BORA). ${ }^{13}$

This paper asserts that internet access is protected within the scope of freedom of expression as an implied right belonging to every person, and that judicial restriction of it as a sentencing condition is an apparent breach of s 14 of BORA. It qualifies this implied right as the right to access the internet free from state interference, rather than an obligation on the state to provide internet access publicly. It then discusses whether either partial or full restrictions of an individual's internet access are legitimised as demonstrably justified limitations under s 5 BORA. A judge's power to impose conditions restricting internet access is constrained due to their obligation to take BORA into account when applying the Sentencing Act. ${ }^{14}$ It concludes by exploring some the practical implications of such restrictions and possible reforms to increase protection of internet access and the clarity of the laws conferring that protection.

\footnotetext{
${ }^{11}$ See: $R$ v Darrell [2013] NZHC 1860; Wilson v New Zealand Parole Board [2013] NZHC 1789; AM v Secretary of State for the Home Department [2011] EWHC 2486 (Admin); United States of America v Dotcom [2013] NZCA 38

${ }^{12}$ AMv Secretary of State for the Home Department [2011] EWHC 2486 (Admin); United States v Mitnick, 145 F.3d 1342, No. 97-50365, 1998 WL 255343 (9 $9^{\text {th }}$ Cir. May 14, 1998)

${ }^{13}$ See: $R$ v Darrell [2013] NZHC 1860; Wilson v New Zealand Parole Board [2013] NZHC 1789.

${ }^{14}$ Paul Rishworth and others The New Zealand Bill of Rights (Oxford University Press, Singapore, 2003) at 141.
} 


\section{Protection of Internet Access in New Zealand}

There is no explicit statutory protection of internet access currently existing in New Zealand. As such, the legal protection of internet access is best found within freedom of expression. Specifically, internet access is protected within the idea that s 14 of the BORA extends to the modes of expression as well as the content.

\section{A Freedom of Expression}

Section 14 of the BORA is the provision which affirms the right to freedom of expression in New Zealand. It provides that:

Everyone has the right to freedom of expression, including the freedom to seek, receive, and impart information and opinions of any kind in any form.

There is no doubt that freedom of expression protects the content of expression, including expression which occurs on the internet. This is confirmed by Police $v$ Slater which proceeded on the basis that content published on a blog was within the ambit of s $14 .{ }^{15}$

Section 14, however, protects more than just the content of expression; the means of expression also fall within its ambit. This is shown by the inclusion of the three modes of expression, "seek, receive, and impart". ${ }^{16}$ This interpretation of s 14 is consistent with its legislative context, the purpose of the provision, and the broad approach applied in human rights law.

\section{Legislative Context}

The language "freedom to seek, receive, and impart information" is not unique to New Zealand. The drafters of the BORA drew on the Universal Declaration of Human Rights (UDHR) and the International Covenant on Civil and Political Rights (ICCPR) when drafting the BORA. This is apparent in s 14, as the words "seek, receive and impart" can also be found in Article 19 of both of the older documents. It is to these documents that one must look when interpreting the words "seek, receive, and impart" because there was

\footnotetext{
${ }^{15}$ Slater v New Zealand Police [2011] DCR 6; HC AK CRI 2010-404-379 (10 May 2011) White J, [45] and [101] show neither party disagreed, [122-123] shows the judge proceeded on that basis.

${ }^{16}$ Andrew Butler and Petra Butler The New Zealand Bill of Rights Act: A Commentary (LexisNexis, Wellington, 2005) at 319.
} 
little discussion of their meaning in the at the time the Bill was enacted, either in the White Paper on the Bill of Rights or by the Select Committee. ${ }^{17}$

Both the ICCPR ${ }^{18}$ and the UDHR ${ }^{19}$ were drafted at a time when there had been international emphasis placed on the importance of freedom of information. ${ }^{20}$ In the United Nations (UN) General Assembly's first session it unanimously adopted Resolution 59(I); the United Nations Declaration on Freedom of Information. ${ }^{21}$ This resolution stated that: ${ }^{22}$

...freedom of information is a fundamental human right and is the touchstone of all freedoms to which the United Nations is consecrated; freedom of information implies the right to gather, transmit, and publish news anywhere and everywhere without fetters.

The major aim of the UN Conference on Freedom of Information, which New Zealand attended, was "improvement in the means of sending information across frontiers in accordance with the view ... that freedom of information is a fundamental human right". ${ }^{23}$

This is the global landscape into which the UDHR and the ICCPR, with their use of "seek, receive, and impart", were enacted. The choice of those words, especially coming from a context of international documents affirming the importance of the free, unfettered flow of information, indicates an intention to protect not just the content of expression, but also the means of expression. This is consistent with the full text of the articles which include the

\footnotetext{
${ }^{17}$ Geoffrey Palmer "A Bill of Rights for New Zealand: A White Paper" [1984-1985] I AJHR A6 at 78-80; Jonathon Penney "Open Connectivity, Open Data: Two Dimensions of the Freedom to Seek, Receive and Impart Information" (2012) 4 VUWLR Working Paper series at 22-23.

${ }^{18}$ Signed in 1966, drafted in 1954

${ }^{19}$ Signed in 1948

${ }^{20}$ Jonathon Penney "Open Connectivity, Open Data: Two Dimensions of the Freedom to Seek, Receive and Impart Information" (2012) 4 VUWLR Working Paper series at 33-39.

${ }^{21}$ Penney, above $\mathrm{n} 20$ at 31; Calling of an International Conference on Freedom of Information GA Res59(I), A/Res/59(I) (1946)

${ }^{22}$ Calling of an International Conference on Freedom of Information GA Res59(I), A/Res/59(I) (1946) at 95.

${ }^{23}$ Penney, above n 20 at 33; as described by John B Whitton who attended the conference: John B Whitton "The United Nations Conference on Freedom of Information and the Movement Against International Propaganda" (1949) 43 American Journal of International Law 73 at 73.
} 
words "through any media" in the UDHR and "through any other media of his choice" in the ICCPR. ${ }^{24}$

Thus, the words "seek, receive, and impart" have a history substantially longer than the 1990 birth of the BORA indicates. ${ }^{25}$ That history, and the importance it placed on the medium as well as the content of expression, militate for the inclusion of both medium and content within the scope of freedom of expression.

\section{Purpose}

The purpose of s 14 may be drawn from the legislative history it shares with Art 19 in the UDHR and the ICCPR, but has also been expounded upon by New Zealand courts and is informed by the underlying rationales for freedom of expression.

In New Zealand, freedom of expression has been ascribed the purpose of enhancing "democratic self-government" as well as advancing knowledge and revealing truth. ${ }^{26}$ All of these purposes are better served by unfettered flow of information, by and among citizens. In today's society, the internet is the ultimate medium for mass communication and the dissemination of information and opinions. ${ }^{27}$ It follows then, that interpreting freedom of expression as extending to a right to internet access is consistent with the purpose of s 14.

The rationales underlying freedom of expression also support the free flow of information. The marketplace of ideas theory states that the market will reach the correct conclusion or "truth" provided it is allowed to function free of external restrictions. ${ }^{28}$ Permitting state

\footnotetext{
${ }^{24}$ Universal Declaration of Human Rights, GA Res 217 A(III), 10 December 1948, Art 19; International Covenant on Civil and Political Rights (adopted 16 December 1966, entered into force 23 March 1976), Art 19(2).

${ }^{25}$ Penney, above n 20 at 43 - there is evidence that the drafters of s 14 knew of this history when drafting the provision. Several of the key sources listed in the White Paper as its key international authorities discussed "freedom of information" as it was understood in the Post-War period, including the background of Arts 19 in both the ICCPR and the UDHR.

${ }^{26}$ Rishworth, above n 14 at 45 .

${ }^{27}$ Penney, above $\mathrm{n} 20$ at 19.

${ }^{28}$ Butler, above n 16 at 307, at 13.6.3.
} 
restriction of internet access is contrary to this theory. One of the criticisms levelled against this theory is that the nature of the media will prevent the truth, other than that which the media prefers, being accepted. ${ }^{29}$ In light of this criticism, the role of the internet as an impartial, uncensored facilitator becomes even more essential as an antidote. Its ability to transmit information form any corner of the globe instantaneously creates a level playing field for information, where all ideas compete for general acceptance on their respective merits.

A second rationale for freedom of expression is the idea that effective functioning of democratic government is premised on freedom of expression. ${ }^{30}$ The internet is an important instrument for uninhibited discussion about the politics of the day; partly because it enables anonymity and partly because discussion need not pass the "gatekeeper" of mainstream media before being disseminated to the public. ${ }^{31}$

Two other grounds have been advanced to explain the importance of freedom of expression; human self-fulfillment and a societal safety-valve. ${ }^{32}$ As regards the former, the internet allows for new forms of expression, such as social media, .gifs, memes and Snapchat, among other internet phenomena. ${ }^{33}$ These have been strongly adopted by internet users with $81 \%$ of New Zealand users belonging to a social networking site ${ }^{34}$ and roughly 30 million people globally using Snapchat each month. ${ }^{35}$ While these examples may seem trivial, they allow new forms of expression which would not exist in their present states without the internet, in turn increasing the options for self-fulfillment through expression. In terms of the latter argument, the internet provides a forum for open and often anonymous discussion of ideas. This prevents ideas being driven underground and becoming

\footnotetext{
${ }^{29}$ Butler, above $\mathrm{n} 16$ at 308 , at 13.6.6.

${ }^{30}$ Butler, above $\mathrm{n} 16$ at 308 , at 13.6.7.

${ }^{31}$ Stephen Thomson "Protecting Legitimate Speech Online: Does the Net work?" (LLB(Hons) Dissertation, University of Otago, 2012) at 3.

${ }^{32}$ Butler, above $\mathrm{n} 16$ at 309 .

${ }^{33}$ www.9gag.com is an enlightening website for both .gifs and memes.

${ }^{34}$ Crothers, above $\mathrm{n} 4$ at 17.

${ }^{35}$ Alyson Shontell "The Truth About Snapchat's Active Users (The Numbers The Company Doesn't Want You To See” (2013) Business Insider www.businessinsider.com
} 
conspiracies. The societal safety-valve argument may be aimed at protecting the content of expression, but the breadth of the internet, and its anonymity, permit people to discuss all ideas without fear of social repercussions.

\section{Broad Approach}

The language of the BORA is intentionally general to indicate the fundamental nature of the rights and allow specification by the interpreter when determining the scope of each right in the particular circumstances. ${ }^{36}$ The courts have traditionally taken advantage of this, by adopting a broad approach when interpreting the scope of rights. ${ }^{37}$ This judicial desire to give rights the least restrictive interpretation possible is exemplified in the Court of Appeal's interpretation of s 14 in Moonen v Film and Literature Board of Review as being "as wide as human thought and imagination". ${ }^{38}$ The broad interpretative approach is in accordance with the treatment of human rights instruments internationally. ${ }^{39}$

The inclusion of the means of expression within the ambit of freedom of expression, including the protection of internet access, is required by the broad approach. It is also an interpretation which is available on the language of the section; "seek, receive, and impart" are not stretched too far by an interpretation which includes a right to internet access.

\section{Conclusion on the Interpretation of $s 14$}

The BORA is subject to a broad and purposive interpretative approach. ${ }^{40}$ Accordingly, interpreting s 14 to extend its protection to a right to internet access is either consistent with, or essential to, the various rationales and purposes underlying freedom of expression. It is also in line with the broad approach, the legislative history and the language of the provision. There is also international support for the protection of internet access as a right, qualified both as a positive obligation on the state and as a freedom from state interference

\footnotetext{
${ }^{36}$ Rishworth, above n 14 at 43.

${ }^{37}$ Rishworth, above n 14 at 43; see Ministry of Transport v Noort CA 369/91 [1992] NZCA 51

${ }^{38}$ Moonen v Film and Literature Board of Review [2000] 2 NZLR 9 (CA) at [15]; also Butler above n 16 at 311.

39 Steven Greer "The Interpretation of the European Convention on Human Rights: Universal Principle or Margin of Appreciation" (2010) 3 UCL Human Rights Review 1 at 6.

${ }^{40}$ Rishworth, above n 14 at 43.
} 
held by citizens. This support, and the reasons that internet access should be conceptualised as a freedom in New Zealand, will be discussed shortly.

In this context it is also helpful to consider the situation in the negative: if s 14 did not include a right to internet access, and that access was then restricted, to what extent would this render the words "freedom to seek, receive, and impart" meaningless? If some information is only accessible online, and individuals are restricted from accessing the internet, then the fact that they have the right to seek and receive that information becomes meaningless. It is the case in today's society that some information is only available online. For example, if an individual wished to view one of the myriad of videos on YouTube, or research academic literature from a foreign university, those are both types of information that would be easily accessible online but practically impossible to obtain without internet access. That the individual has a right to fruitlessly seek the information must be cold comfort indeed.

\section{B Right or Freedom: Is there a positive obligation on the government?}

Rights can be conceptualised in two ways: 'negative' rights or freedoms require the government to refrain from action that interferes with the right, while 'positive' rights require the government to act, or provide a service, in order to satisfy the right. ${ }^{41}$ Either would mean that judicial restrictions on internet access in sentencing are contrary to freedom of expression, however the author argues that only the right to access the internet free from state interference exists in New Zealand, and not a positive obligation on the government.

Freedom of expression itself is framed as a negative right, and although the government has been encouraged to facilitate it, it has no explicit obligation to provide fora for public expression. ${ }^{42}$ It would thus be unusual to qualify internet access as a positive obligation on

\footnotetext{
${ }^{41}$ Aeon Skoble "Positive Rights vs. Negative Rights" (29 June 2011) Learn Liberty www.learnliberty.org

42 See F. La Rue's report for an example of encouragement, above n 3; Butler, above n 16 at 322 re: no duty to provide fora. Also note that there is growing sentiment that in order to promote and facilitate freedom of expression there may be a developing argument for a positive obligation on the state to provide access to
} 
the government, where it is protected by a negatively framed right, which confers no such obligation. It is also worth noting that the drafting history of the BORA explicitly omits socio-economic or 'positive' rights, so it falls within the overall scheme of the Act to qualify the right to internet access as a freedom from government interference. ${ }^{43}$ Butler and Butler state that the right to seek information does not mean that the state has to make a certain medium available. ${ }^{44}$

Conceptualising internet access as a freedom, rather than a right is consistent with the purposes of $\mathrm{s} 14$, identified earlier. The freedom to access the internet conforms to maintaining the effective functioning of democracy and the advancement of truth. The freedom of access is sufficient to meet those purposes in New Zealand, though in other, less developed states that conclusion may differ. This is because New Zealand already has high levels of internet access and most public libraries have computers capable of accessing the internet available for public use. State restriction of internet access, as a condition in sentencing for example, will still be a breach of s 14 even where the right of internet access is qualified as freedom from state interference rather than as a positive obligation.

\section{International Approach}

Human rights attach to people because they are human, not because they are citizens of a particular state. ${ }^{45}$ Therefore, it is pertinent to consider how other countries have treated freedom of expression and the issue of whether its ambit includes protection of the means of expression, specifically internet, when interpreting the right in New Zealand.

\footnotetext{
means of communication, but the author believes that it does not yet exist in New Zealand for the reasons given and it is outside of the scope of this paper.

${ }^{43}$ Penney, above $\mathrm{n} 20$ at 46.

${ }^{44}$ Butler, above $\mathrm{n} 16$ at 319.

${ }^{45}$ Susy Frankel (ed), and others Learning from the Past, Adapting for the Future: Regulatory Reform in New Zealand (LexisNexis, Wellington, 2011) at 9.3.1(d).
} 


\section{Case Law}

In New Zealand there is scant case law about the scope of the "freedom to seek, receive and impart information" and whether it includes a right of access to any mediums. ${ }^{46}$ Federated Farmers of New Zealand held that s 14 included the freedom to send and receive mail, demonstrating a judicial acceptance of the freedom to access a means of expression as within the words of s $14 .{ }^{47}$ Morse $v$ The Police continues in this vein by saying that protest and the right to protest in an effective way are aspects of freedom of speech, and that it is legitimate for those wishing to protest to make choices regarding the most effective way of doing so. ${ }^{48}$ This supports the idea that the means of expression are protected from state interference, including an individual's choice as to the most effective means.

Conversely, Ransfield establishes that the right to impart information does not contain the right to an audience. ${ }^{49}$ However, this is not inherently contrary to the protection of internet access within s 14, or the preceding cases, it simply outlines the distinction between a right conferring a positive obligation on the state, and one requiring the state not to interfere with the right. Ransfield is correctly interpreted as holding that the state need not provide citizens with the means to impart information, which in that case was access to a radio station. However, this has no impact on the right to access mediums of expression, such as the internet, free from state interference, which is consistent with Federated Farmers and Morse.

Internationally, there has been more judicial exploration of whether the "freedom to seek, receive, and impart information" confers a right to access a medium of expression. In Germany, the Bavarian Constitutional Court held that a council ban on satellite dishes where there was no other adequate television reception was an infringement of freedom of expression. ${ }^{50}$ This indicates that where there is only one medium for expression, the

\footnotetext{
${ }^{46}$ Penney, above $\mathrm{n} 20$ at 19.

${ }^{47}$ Federated Farmers of New Zealand $v$ New Zealand Post Ltd CP No 661/92 [1992] at 55; Rishworth, above n 14 at 311.

${ }^{48}$ Morse v The Police [2011] NZSC 45 at [108].

${ }^{49}$ Ransfield $v$ Radio Network Ltd [2005] 1 NZLR 233 at [34]; see also Butler above n 16 at 322.

${ }^{50}$ BayVerfGH. DOV 1986, 72, 74 see Butler, above n 16 at 319.
} 
freedom to access that medium is contained within the ambit of freedom of expression. This is consistent with the situation outlined in the negative above; it indicates that where a government restriction on access to a medium would make the rights held by citizens hollow, access to that medium is protected. ${ }^{51}$

This reasoning is affirmed in another German case with a similar result where a landlord refused a Turkish tenant's request to install a satellite dish in order to access Turkish television and radio. There the court held that the landlord must allow the satellite dish as it was the only way for the tenant to access the information. ${ }^{52}$

In Autronic $v$ Switzerland the court held that the Swiss authority's refusal to allow a company to receive a satellite broadcast of a television program was a violation of the company's right to receive information. ${ }^{53}$ There, the European Court of Human Rights stated that: ${ }^{54}$

...[freedom of expression] applies not only to the content of information but also to the means of transmission or reception since any restriction imposed on the means necessarily interferes with the right to receive and impart information.

The court then clarified that the reception of television programs by means of an aerial came within freedom of expression without it being necessary to establish the purpose for which the right was exercised. ${ }^{55}$

Thus the European Court of Human Rights' position on article 10, which protects the right to "receive and impart information and ideas without interference by public authority", can be said to include a right not to be impeded in one's efforts to access available information. ${ }^{56}$ This is consistent with the interpretation of s 14 of the NZBORA including a right to internet access free from state interference.

\footnotetext{
${ }^{51}$ See 'Conclusion on the Interpretation of s 14' above.

52 BVerfG NJW 1994, 1147 see Butler, above n 16 at 320.

${ }^{53}$ Autronic AG v Switzerland (1990) 12 EHHR 485 (ECHR).

${ }^{54}$ Autronic AG v Switzerland above n 53 at [47].

${ }^{55}$ Autronic AG v Switzerland above n 53 at [47].

${ }^{56}$ Butler, above n 16 at 320.
} 
France offers the first case where freedom of expression was used to protect internet access from government interference. In 2009 the Conseil Constitutionnel found a copyright infringement law (known as HADOPI), which allowed the government to cut off citizens' internet access for repeat copyright infringements, to be an unconstitutional restriction on citizens' right to free expression and communication. ${ }^{57}$ However, the Conseil did not qualify internet access as a right, but as a condition for the enjoyment of freedom of communication, stating that: ${ }^{58}$

'...in the current state of the means of communication and given the generalized development of public online communication services and the importance of the latter for participation in democracy ... [freedom of expression] implies freedom to access such services'.

A decision by the Costa Rican Constitutional Court in 2010 followed and referred to the French decision. The judgment acknowledged the importance of information technologies for facilitating the exercise of fundamental rights and democratic participation, then went further by affirming a fundamental right that covers access to such technologies, namely, the right of access to the internet. ${ }^{59}$ It described this right as a "constitutional right of access to new information technologies". 60

These international cases largely arose due to insufficient access to a medium of communication, which as I have mentioned earlier is not at issue in New Zealand in regards to the internet. ${ }^{61}$ However, they still stand as authority that where there is no other means of accessing information, access to a particular medium will be protected under freedom of expression. As the internet will at times be the only means of accessing information,

\footnotetext{
${ }^{57}$ Penney, above $\mathrm{n} 20$ at 3;

${ }^{58}$ Decision no. 2009-580 Act furthering the diffusion and protection of creation on the Internet (2009) The Constitutional Council at [12]. Also see Declaration of the Right of Man and the Citizen 1789 (France), Art 11.

${ }^{59}$ Andres Oviedo Guzman v Ministerio de Ambiente, Energia y Telecommunicaciones No. 2010-012790, July 30 2010, Sala Constitucional de la Corte Suprema de Justicia de Costa Rica [Constitutional Chamber of the Supreme Court] (Costa Rica) at [V].

${ }^{60}$ Guzman v Ministerio de Ambiente, Energia y Telecommunicaciones, above n 59 at [V].

${ }^{61}$ See 'Right or Freedom: is there a positive obligation on the government' above.
} 
these cases support an interpretation of s 14 that protects internet access from state interference. Furthermore, in the only cases which considered internet access broadly, rather than access to a medium for a specific purpose, the courts held that a general right to internet access existed, either as a freedom from state interference within freedom of expression or as a right in itself. ${ }^{62}$ This indicates that where courts are made to face the issue of internet access broadly, and state restrictions thereof, they are willing to step up and hold that internet access in general, not just for specific information which is otherwise inaccessible, is protected from state interference under freedom of expression.

\section{Statute}

International statutes are also important when considering whether freedom of expression includes an implied right to internet access because they indicate the importance placed on internet access as a right globally. Internationally, there have been two main ways of protecting internet access: by legislative affirmation of internet access as a right, or by enacting a statutory Universal Service Doctrine.

Only a few recent constitutions have specific provisions concerning access to telecommunications mediums. Greece was the first country to constitutionally recognize the right to participate in the information society, including by access to electronically transmitted information, ${ }^{63}$ and was followed in 2003 by Honduras, which amended the constitution to recognise a right to access personal information by any medium. ${ }^{64}$ Ecuador's constitution is the most explicit and protects the right to access information and communication technologies. ${ }^{65}$

The Universal Service Doctrine refers to the practice of providing a base uniform level of services to every citizen of a country, regardless of location. ${ }^{66}$ It was created for other public services but has been applied to internet access in Estonia and Finland. Article 5 of

\footnotetext{
62 The French and Costa Rican cases referred to.

63 The Constitution of Greece 1975 (Amended 2001), Art 5A.

${ }^{64}$ Constitution of Honduras 1982 (Amended 2003), Art 182.

${ }^{65}$ Constitution of Ecuador 2008, Art 16.

${ }^{66}$ See Federal Communications Commission "Universal Service” (2014) www.fcc.gov
} 
the Estonian Telecommunications Act requires that internet is universally available to citizens regardless of localisation and at a uniform cost. ${ }^{67}$ Finland passed similar legislation in 2009, going even further by specifying the minimum speed of access that must be provided. ${ }^{68}$

Statutory protections, particularly constitutional ones, are likely to be less common than cases affirming the importance of internet access and its value as a right. The reasons for this are twofold. First, only constitutions and Bills of Rights which have been drafted since the advent of the internet and the recognition of its importance are likely to have included explicit references to the internet. Secondly, legislation is a slow process. Governments are less likely to enact statutes protecting internet access, and thus potentially take upon themselves positive obligations to provide such access, without careful and lengthy consideration, and either a perceived need or public demand. Therefore, despite the fact that there are few examples of explicit statutory protection of internet access, the existence of statutory protection at all, and the range of countries where it is found go some way to demonstrate the international acknowledgement of the importance of internet access and its role as a right.

\section{State Restriction of Internet Access}

\section{Infringement of $s 14$}

Infringement of s 14 will occur when a judge imposes a special condition restricting internet access in the course of sentencing an offender. This will generally only occur when the internet has played a role in the offending. The Sentencing Act 2002 allows for special conditions to be imposed in specific circumstances, where the offender is being sentenced

\footnotetext{
${ }^{67}$ Telecommunications Act 2000 (Estonia), Art 5. The provision is enforceable against ISPs, who are required to guarantee access to all citizens. This has been practically successful with Estonia having some of the highest rates of access globally.

${ }^{68}$ Communications Market Act 2009 (Finland), Art 60: providers must guarantee users an appropriate internet connection (broadband) at their domicile at reasonable cost without discrimination based on location. Communications authority (FICORA) tasked with verifying costs applied by providers. Standard is $1 \mathrm{mb} / \mathrm{s}$ everywhere.
} 
to supervision, intensive supervision, home detention, imprisonment of not more than 24 months or post-detention conditions. ${ }^{69}$ Except in the case of imprisonment, these conditions may only be imposed if the court is satisfied that: ${ }^{70}$

(a) There is a significant risk of further offending by the offender; and

(b) Standard conditions alone would not adequately reduce that risk; and

(c) The imposition of special conditions would reduce the likelihood of further offending by the offender through the rehabilitation and reintegration of the offender.

In all of the above cases, again with the exception of imprisonment, a subsection allows the imposition of "any other conditions that the court thinks fit to reduce the likelihood of further offending by the offender". ${ }^{71}$

Under these provisions, a judge may make an order restricting internet access if he or she believes that there is a significant risk of further offending by the offender which standard conditions alone would not address, and that the restriction of internet access would reduce the likelihood of further offending by the offender through their rehabilitation and reintegration.

Section 93 applies where an offender is released from short-term imprisonment. It allows a court to impose special conditions on the offender if they are designed to: ${ }^{72}$

(a) Reduce the risk of reoffending by the offender; or

(b) Facilitate or promote the rehabilitation and reintegration of the offender; or

(c) Provide for the reasonable concerns of victims of the offender.

Section 15(3) of the Parole Act 2002 gives a non-exhaustive list of special conditions, introduced by the words "special condition[s] include, without limitation -“. Therefore a special condition restricting internet access is within the law for a judge to impose

\footnotetext{
${ }^{69}$ Sentencing Act 2002, ss 52, 54I, 80D, 80P and 93.

${ }^{70}$ Sentencing Act 2002, ss 80P(1), 80D(2), 52(1), 54I(1).

${ }^{71}$ Sentencing Act 2002, ss 80P(2)(d); s 80D(4)(e); s 52(2)(c); s 54I(3)(e).

72 Sentencing Act 2002, s 93(3), note 'short term' means 12 months or less.
} 
following short-term imprisonment, as was done in Bowers $v$ Department of Corrections. ${ }^{73}$ However, where the condition restricting internet access is an apparent infringement of $s$ 14 and it is not legitimised by s 5 it will be unlawful for a judge to impose that condition on an offender. This is because when exercising their discretion judges are bound to consider and follow the BORA. ${ }^{74}$

\section{E Possible Restrictions}

Before considering the legality of restrictions, it is important to know what they might consist of. In the United States courts have made various orders restricting internet access: in some cases this has involved a total ban from internet access; in others, a partial ban has been applied..$^{75}$ The United Kingdom also has some case history of internet restrictions. These have included: not to possess any form of internet access without informing the police; not to use any computer which does not retain the internet history and not to refuse to show such history to a police officer on request, and; not to use the internet for any purpose other than employment, study, work, lawful recreation or the purchase of goods or services. $^{76}$

Total bans, as the name suggests, involve a complete restriction of any internet access including from computers, smart phones and tablets. Partial bans are anything less, and may involve allowing the offender to access only specific websites, restricting the offender to use of a specified computer, requiring internet access only under the supervision of a specified person, or any other restriction on internet access which is less than a total ban. In a recent New Zealand case the offender was ordered not to access, use or be in the possession of any equipment capable of accessing the internet without the prior written approval of his probation officer. ${ }^{77}$ In other New Zealand cases offenders have been ordered not to use or possess internet-capable devices unless supervised by an approved

\footnotetext{
${ }^{73}$ Bowers v Department of Corrections Wellington CRI-2011-485-12, 5 April 2011 at [3].

${ }^{74}$ Rishworth above $\mathrm{n} 14$ at 141.

${ }^{75}$ Cheryl Krause and Luke Pazicky "An Un-Standard Condition: Restricting Internet Use as a Condition of Supervised Release" (2008) 20 WCSL 201 at 201-202.

${ }^{76} R v$ Smith [2011] EWCA Crim 1772 at [19].

${ }^{77} R v$ Needham [2014] NZHC 736 at [83].
} 
adult, to provide access to any electronic devices for the purpose of a control officer checking compliance with special conditions, and not to enter any retail outlet that sells electronic equipment. ${ }^{78}$

\section{F Section 5 Analysis}

The ad hoc balancing approach advocates a two-stage process of defining the rights broadly, regardless of competing considerations, and then determining the reasonableness of any limitations separately in an application of s $5 .^{79}$ Section 14 has been broadly defined above as including the right to access the internet free from state interference.

Section 5 states: ${ }^{80}$

Justified limitations - subject to section 4 of this Bill of Rights, the rights and freedoms contained in this Bill of Rights may be subject only to such reasonable limits prescribed by law as can be demonstrably justified in a free and democratic society.

\section{Prescribed by Law}

Section 5 requires that any limits placed on a right must be prescribed by law. "Prescribed by law" means that limits must not be arbitrary and must be clearly accessible. ${ }^{81}$ According to the Ministry of Justice's summary of case annotations, a law that confers a discretion on an official to act in derogation of a right will satisfy the prescribed by law requirement, so long as the discretion is constrained by legal standards. ${ }^{82}$ Where a judge imposes a special condition restricting internet access, they are exercising the discretion conferred upon them by the Sentencing Act. As described above, judges may only impose special conditions subject to certain requirements outlined in the Sentencing Act. ${ }^{83}$ Thus, a restriction of

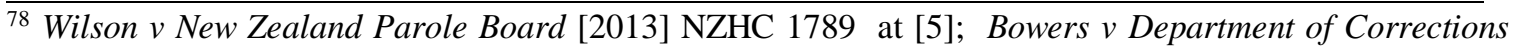
above $\mathrm{n} 73$ at [4].

${ }^{79}$ Butler above $\mathrm{n} 16$ at 120 .

${ }^{80}$ The Bill of Rights Act 1990, s 5.

${ }^{81}$ Hansen $v R$ [2007] 3 NZLR 1 at [180].

${ }^{82}$ Ministry of Justice "NZ Bill of Rights Act 1990: Summary of Case Annotations Ministry of Justice Section 5" (1997) www.justice.govt.nz; this is consistent with Rishworth's commentary which notes that limits may arise by implication, Rishworth above n 24 at 175.

${ }^{83}$ See 'Infringement of s 14' above.
} 
internet access imposed as a special condition in accordance with the Sentencing Act will constitute a limit on freedom of expression which is prescribed by law.

\section{Demonstrably Justified in a Free and Democratic Society}

Tipping $\mathrm{J}$ in $R v$ Hansen outlined the s 5 methodology as raising two issues. The first is whether the limiting measures serve a purpose sufficiently important to justify curtailment of the right or freedom. The second he split into three parts; whether the limiting measure is rationally connected to its purpose; whether the limiting measure impairs the right or freedom no more than is reasonably necessary for sufficient achievement of its purpose, and; whether the limit is in due proportion to the importance of the objective. ${ }^{84}$ I will assess these in turn.

(a) Does the limiting measure serve a purpose sufficiently important to justify the curtailment of freedom of expression?

The purposes of a restriction of internet access in the case of internet related crime are largely to be found in the principles of sentencing. Restricting the internet access of an offender, either fully or in part, is likely to protect the public and reduce or prevent recidivism by aiding the rehabilitation of the offender and possibly acting as a deterrent on others who rely on the internet and are considering using it in the pursuit of crime. ${ }^{85}$ The option for a judge to restrict internet access may also allow for a community sentence in some cases where, due to the nature of the offending, the judge may otherwise feel compelled to sentence a term of imprisonment.

In terms of prevention of future offending, this consideration gains significance when the harm considered is something in the realm of child pornography, or blackmail, rather than other cybercrime. This is because those crimes are not 'victimless' and the harm is more

\footnotetext{
${ }^{84}$ Hansen $v R$ above $\mathrm{n} 81$ at [104].

${ }^{85}$ Krause and Pazicky above n 75 at 203.
} 
than financial. Other jurisdictions have also imposed access restrictions where there were risks to national security posed by offenders through their internet use. ${ }^{86}$

It is essential to note that the importance of the purpose of preventing further crime will vary in each case depending on factors such as the nature of the risk and the severity of the restriction. While in some circumstances that purpose may be sufficient to justify some curtailing freedom of expression, in others it will fall short. As has been belaboured by many an academic: it all depends on the facts of the case.

\section{(b) Rational Connection}

The restriction of internet access in the case of internet-related crimes as a means of preventing further crime of the same type is rationally connected with its purpose. Without internet access, or with restricted access, perpetrators will be less able to reoffend using the internet. As their offending was internet-based previously, it follows that the restrictions will be effective in reducing their likelihood of reoffending.

(c) Does the limiting measure impair the freedom no more than is reasonably necessary for sufficient achievement of its purpose?

In his application of s 5 in Hansen, Tipping described this inquiry in practical terms as involving consideration of "whether Parliament might have sufficiently achieved its objective by another method involving less cost to the [right infringed]" ${ }^{87}$ In the case of internet access, full and partial restrictions may be placed in the alternative as methods for reducing internet-based crime. Supervision and rehabilitation programs are also sentencing options, and do not impair freedom of expression.

Full and partial access restrictions would both reduce the likelihood of the offender committing more internet-based crimes. A total access restriction evidently impairs

\footnotetext{
${ }^{86}$ Alasdair Henderson "National security concerns do trump human rights, sometimes" (2011) UK Human Rights Blog www.ukhumanrightsblog.com

${ }^{87}$ Hansen $v R$ above $\mathrm{n} 81$ at [126].
} 
freedom of expression to the largest degree. Consequently it should be avoided except where it is necessary to sufficiently prevent or reduce internet-based crime. Whether it is necessary will depend on the circumstances of the case. In the case of terrorism aided by internet-use, such as in AMv Secretary of State for the Home Department, an absolute or near absolute restriction on internet access may be necessary to prevent the harm occurring at all. ${ }^{88}$ Conversely, an American article which considers American case law on the subject, argues that: ${ }^{89}$

...as a legal matter, in most cases, banning cyber criminals from ever using the internet restricts their liberty more than is necessary to protect society. Prophylactic conditions... can protect the public as effectively as a ban.

In cases of first time, or minor offending, or where it is appropriate for other reasons, supervision or rehabilitation programs may be effective in preventing further internetbased crime. Where this is the case these methods must be applied as they do not infringe s 14, and judges are obliged to act consistently with the BORA where possible. In situations where the offender is unsophisticated with computers and unlikely to circumvent the restriction, or where the potential harm is less extreme, a partial restriction may be sufficient to reduce or prevent the harm.

Thus, the method which will sufficiently prevent further internet-based offending, while infringing on freedom of expression as little as possible, will depend on the particular circumstances of the case. Terrorism, where it is imperative to prevent any future offences due to their gravity, or cybercrimes, where the offender is likely to circumvent lesser measures, may require the order of a total access restriction in order to sufficiently achieve their respective purposes. In cases where supervision or rehabilitation are inappropriate, a partial restriction may be necessary to sufficiently prevent reoffending. It is likely that the majority cases would require only a partial, or no, access restriction in order to reduce the likelihood of reoffending. Only the cases of the utmost severity involving immense harm, or repeat offending and technological sophistication may require a full access restriction in order to prevent reoffending.

\footnotetext{
${ }^{88}$ AMv The Secretary for the Home Department above $\mathrm{n}$ 12, at [106].

${ }^{89}$ Krause and Pazicky above at n 75 at [203].
} 
(d) Proportionality

The proportionality inquiry involves consideration of whether the limit is in due proportion to the importance of the objective. The United Kingdom Court of Appeal has said that a blanket prohibition on internet access is impermissible in the context of child pornography. ${ }^{90}$ The court added that it is disproportionate because it restricts the defendant in the use of what is nowadays an essential part of everyday living for a large proportion of the public. It likened such a prohibition to banning an offender from all printed material because he was found with pictures of child pornography. However, the British High Court in another case found that a near-total internet restriction was proportionate where it related to national security. ${ }^{91}$

A consideration of those decisions together indicates that in the United Kingdom protecting the public from "serious sexual harm" is not sufficiently important to justify a total ban from internet access, ${ }^{92}$ whereas protecting members of the public from a risk of terrorism is. ${ }^{93}$ This underlines both the stringent standard required by the proportionality inquiry and the sometimes slight distinction between the proportionate and disproportionate, as no one would suggest that either of those objectives was lacking in importance. An American case demonstrates the approach in less serious cases, where a review court found a thirty-year total computer ban to be unreasonable in light of the fact that no one was actually harmed as a result of the crime. ${ }^{94}$

American commentators Krause and Pazicky argue that "in all but the most extreme cases, ordering a total ban defies law, equity and sound public policy". 95 The author proposes that this is the correct approach, if somewhat dramatically worded. A total access restriction infringes so much on the right to freedom of expression that only in the most extreme cases,

\footnotetext{
${ }^{90} R v$ Smith above $\mathrm{n} 76$ at [20]i.

${ }^{91} A M v$ The Secretary for the Home Department above n 12, at [120].

${ }^{92} R v$ Smith above $\mathrm{n} 76$ at [6].

${ }^{93}$ AMv The Secretary for the Home Department above n 12, at [9].

${ }^{94}$ United States v. Russell, 600 F.3d 631 (D.C. Cir. 2010) at 637.

${ }^{95}$ Krause and Pazicky above at n 75 at [203].
} 
where the objective is imperative, will it be proportionate. Nevertheless, more tailored restrictions may well be proportionate to the objective of preventing reoffending. Child pornography, cyberstalking, and blackmail are not trivial crimes, and their prevention is an important aim.

\section{Conclusion on 5}

A total internet restriction is a prima facie breach of s 14 and will remain so except in the most extreme cases where it may be justified under s 5. Protecting national security interests may be one case where a total access restriction may be justified. However, it is important to keep in mind that the restriction must be both necessary and proportionate. In the case of cybercriminals with advanced computer knowledge, a full restriction may be necessary to prevent circumventing lesser restrictions and thus reoffending, but it may not be proportionate to the objective.

Lesser restrictions will more easily be legitimised by s 5 , as necessary and proportionate and therefore justified. This is consistent with the purposes of s 14 as partial restrictions are likely to most severely limit reoffending, while only somewhat interfering with the offender's ability to participate in New Zealand's democracy or to send and receive legitimate information.

\section{G Section 6}

Relying on Tipping J's approach in Hansen, where a provision infringing on a right fails to be legitimised by s 5 , the courts must consider whether there is a rights-consistent interpretation of that provision available.

The provisions of the Sentencing Act relating to special conditions are at issue in this case, and have been outlined above. These provisions do not explicitly empower judges to restrict internet access as a special condition; they do, however, leave open to the sentencing judge the power to impose any condition they think fit, so long as it meets certain conditions. On its language, internet access restrictions can easily be read into the Sentencing Act as special conditions. However, it is equally possible for a court to interpret the Act as implicitly excluding conditions that unjustifiably infringe the rights of the 
individual being sentenced. The latter approach seems to be required by s 6 , in fact, which states: ${ }^{96}$

Wherever an enactment can be given a meaning that is consistent with the rights and freedoms contained in this Bill of Rights, that meaning shall be preferred to any other meaning.

When Parliament enacted the Sentencing Act, it must have intended to infringe on human rights to some extent. The nature of the Act is to impose penalties on criminals, including imprisonment which severely impacts on multiple human rights including freedom of movement and liberty of the person. However, it is reasonable to interpret the Act as not empowering the imposition of sentences which unjustifiably limit the rights found in the BORA, unless explicitly stated. The provisions relating to special conditions, which have been relied on to impose internet restrictions in New Zealand, do not thus empower special conditions which constitute unjustified limitations to human rights, specifically the right to freedom of expression including the right to access the internet free from state interference.

\section{Practical Considerations}

Even where a judge legitimately orders the restriction of access, its implementation still stands in issue. There are various practical considerations which may prove problematic when imposing special conditions restricting internet access.

Partial restrictions involving unannounced hard drive inspections or monitoring software are very achievable technologically, but may increase the costs on the government. ${ }^{97}$ The added costs may consist of training parole officers, buying the software or simply the extra man-hours spent in enforcing them. A sentencing judge may order the offender to pay for software themselves, but a technologically savvy offender may be able to overcome any partial restrictions placed on them. For someone experienced with computers, the most effective way to enforce a restriction might be by cooperating with an Internet Service

\footnotetext{
96 The Bill of Rights Act 1990 , s 6.

${ }^{97}$ Krause and Pazicky above at n 75 at [203].
} 
Provider, but this may prove impractical if restrictions are employed often and for short time-periods.

Does this then advocate full restrictions for cybercriminals? A full restriction may be easier to enforce, requiring only the assurance of no internet access, something parole officers will be more easily able to recognise. However, a full restriction has a much more serious effect on the life of the offender, significantly intruding on his or her right to freedom of expression. Is it possible to justify such an approach to economic or intellectual property crimes, when a lesser restriction might be applied to offenders in victim-based crimes, such as possession of child pornography, or cyber-stalking, purely because they are less likely to circumvent restrictions? These are questions that will need to be faced head-on by any judge ordering an internet restriction. Account must also be taken of the effect a total access restriction would have on the offender's ability to take part in society, for example through social media and news sites, even attending university, and also the effect on other members of the household. A significant restriction on one's ability to take part in important aspects of society may lead to anti-social behaviour and reoffending. For a person trained in the Information Technology industry, a total ban would seriously impair their ability to get a job in that field, and, if paired with a fine, may also contribute to recidivism as a form of economic survival. In fact, many professions now require internet use and so total bans would seriously impair an offender's ability to get a professional job.

It is also relevant to note the courts' lack of technological expertise. Judges may not be best placed to understand the practicalities of an internet restriction. This increases the importance of counsel in sentencing hearings as a source of information for the judge. It also indicates the judges making these orders should perhaps undertake some information technology training to better understand the realities, or obtain advice from someone experienced in the field.

\section{$V$ Conclusion}

In New Zealand s 14 protects the mode of expression alongside the content, as shown by the inclusion of the words "seek, receive and impart". Citizens' access to the internet is 
thus protected from state interference by the BORA, although this protection does not go so far as to oblige the state to provide internet access for the New Zealand public. This interpretation is consistent with the historical legislative context of freedom of expression, the broad and purposive interpretation afforded to human rights, the underlying rationales for freedom of expression as well as New Zealand and international case law. It is also in accord with growing international sentiment about the importance of unrestrained internet access, shown in the increasing reliance of people and organisations, including governments, on the internet, and the international move towards protecting access whether by specific legislation or UN reports.

Judicial restrictions of internet access as a special condition of sentencing are apparent infringements of freedom of expression. Partial restrictions of internet access may be justifiable where they are aimed at preventing reoffending and are proportionate to that aim, but total restrictions, though a possibility, are unlikely to be proportionate in anything but cases of the most egregious offending. This is because of the negative impact that a total restriction would likely have on the ability of an individual to participate in society. Where a judge has imposed an unjustified restriction of internet access an offender may appeal and have the condition revoked on the basis that it is contrary to the BORA.

To date, in the New Zealand cases where internet restrictions have been imposed in sentencing, there appears to have been no judicial discussion about the infringement of freedom of expression, or proportionality in that regard. This is concerning as transparency is particularly important in the field of human rights, and because it appears there has been no judicial consideration of whether orders restricting internet access do, in fact, infringe on freedom of expression and are thus unlawful. There are also various considerations about the practical implementation of such conditions that will need to be explored further if the use of internet restrictions in sentencing continue and develop in New Zealand.

Going forward, New Zealand could follow in the footsteps of Estonia and Finland and adopt a Universal Service Doctrine, or explicitly recognise a right to internet access in statute. Any reform would be able to clarify the extent of the right to internet access, and whether it created a positive obligation on the government to provide public access. The 
Green Party has launched an 'Internet Rights Bill' which proposes to guarantee internet access to citizens as one of its rights, but this has not yet become New Zealand law. ${ }^{98}$ Regardless of possible reforms, there is a global shift towards recognition of the internet as an important medium of communication which foretells an increasing acceptance of a right to internet access and greater scrutiny of state restrictions to access.

${ }^{98}$ Internet Rights and Freedoms Bill (Draft Bill), s 12 
Bibliography

\section{Legislation}

New Zealand

Sentencing Act 2002

The New Zealand Bill of Rights Act 1990

International

Communications Market Act 2009 (Finland).

Constitution of Ecuador 2008 (Ecuador).

Constitution of Greece 1975 (Amended 2001) (Greece).

Constitution of Honduras 1982 (Amended 2003) (Honduras).

Declaration of the Right of Man and the Citizen 1789 (France).

Telecommunications Act 2000 (Estonia).

\section{Cases}

\section{New Zealand}

Bowers v Department of Corrections Wellington CRI-2011-485-12, 5 April 2011.

Federated Farmers of New Zealand $v$ New Zealand Post Ltd CP No 661/92 [1992]

Hansen v R [2007] 3 NZLR 1.

Moonen v Film and Literature Board of Review [2000] 2 NZLR 9 (CA).

Morse v The Police [2011] NZSC 45.

$R v$ Darrell [2013] NZHC 1860

$R v$ Needham [2014] NZHC 736.

Ransfield v Radio Network Ltd [2005] 1 NZLR 233.

Slater v New Zealand Police [2011] DCR 6; HC AK CRI 2010-404-379 (10 May 2011).

United States of America v Dotcom [2013] NZCA 38.

Wilson v New Zealand Parole Board [2013] NZHC 1789.

\section{European}

Autronic AG v Switzerland (1990) 12 EHHR 485 (ECHR).

BayVerfGH. DOV 1986

BVerfG NJW 1994, 1147

Decision no. 2009-580 Act furthering the diffusion and protection of creation on the Internet (2009) The Constitutional Council. 


\section{United Kingdom}

AM v Secretary of State for the Home Department [2011] EWHC 2486 (Admin)

$R v$ Smith [2011] EWCA Crim 1772

United States of America

United States v Mitnick, 145 F.3d 1342, No. 97-50365, 1998 WL 255343 ( $9^{\text {th }}$ Cir. May 14, 1998)

United States v. Russell, 600 F.3d 631 (D.C. Cir. 2010) at 637.

Other

Andres Oviedo Guzman v Ministerio de Ambiente, Energia y Telecommunicaciones No. 2010012790, July 30 2010, Sala Constitucional de la Corte Suprema de Justicia de Costa Rica [Constitutional Chamber of the Supreme Court] (Costa Rica).

\section{Treaties}

European Convention for the protection of Human Rights and Fundamental Freedoms (entered into force 3 September 1953).

International Covenant on Civil and Political Rights (adopted 16 December 1966, entered into force 23 March 1976).

\section{United Nations Materials}

United Nations General Assembly, Report of the Special Rapporteur on the promotion and protection of the right to freedom of opinion and expression, Frank La Rue (Human Rights Council, 17 ${ }^{\text {th }}$ session, 16 May 2011, A/HRC/17/27)

Universal Declaration of Human Rights, GA Res 217 A(III), 10 December 1948

Calling of an International Conference on Freedom of Information GA Res59(I), A/Res/59(I) (1946).

\section{Texts}

Andrew Butler and Petra Butler The New Zealand Bill of Rights Act: A Commentary (LexisNexis, Wellington, 2005).

Paul Rishworth and others The New Zealand Bill of Rights (Oxford University Press, Singapore, 2003).

Susy Frankel (ed), and others Learning from the Past, Adapting for the Future: Regulatory Reform in New Zealand (LexisNexis, Wellington, 2011)

Susy Frankel, Deborah Ryder (eds) and others Recalibrating Behaviour: Smarter Regulation in a Global World (LexisNexis, Wellington, 2013). 


\section{Articles}

Cheryl Krause and Luke Pazicky "An Un-Standard Condition: Restricting Internet Use as a Condition of Supervised Release" (2008) 20 WCSL 201.

Jonathon Penney "Open Connectivity, Open Data: Two Dimensions of the Freedom to Seek, Receive and Impart Information" (2012) 4 VUWLR Working Paper series.

Stephen Thomson "Protecting Legitimate Speech Online: Does the Net work?" (LLB(Hons) Dissertation, University of Otago, 2012) .

Steven Greer "The Interpretation of the European Convention on Human Rights: Universal Principle or Margin of Appreciation" (2010) 3 UCL Human Rights Review 1.

\section{Internet Materials}

Aeon Skoble "Positive Rights vs. Negative Rights" (29 June 2011) Learn Liberty www.learnliberty.org.

Alasdair Henderson "National security concerns do trump human rights, sometimes" (2011) UK Human Rights Blog www.ukhumanrightsblog.com.

Alyson Shontell “The Truth About Snapchat's Active Users (The Numbers The Company Doesn't Want You To See" (2013) Business Insider www.businessinsider.com.

Barry Leiner and others "Brief History of the Internet" (accessed 2014) Internet Society www.internetsociety.org.

Federal Communications Commission "Universal Service” (2014) www.fcc.gov.

Internet Live Stats "Internet Users" (2014) Internet Live Stats www.internetlivestats.com. www.9gag.com.

Ministry of Justice "NZ Bill of Rights Act 1990: Summary of Case Annotations Ministry of Justice - Section 5" (1997) www.justice.govt.nz.

\section{Reports}

C Crothers and others (2014) Internet Trends in New Zealand 2007-2013 Auckland, New Zealand: Institute of Culture, Discourse and Communication, Auckland University of Technology

Geoff Bascand "Household Use of Information and Communication Technology: 2012" (2013) Statistics New Zealand

\section{Government Materials}

Geoffrey Palmer “A Bill of Rights for New Zealand: A White Paper” [1984-1985] I AJHR A6. Internet Rights and Freedoms Bill (Draft Bill). 
Word count

The text of this paper (excluding table of contents, footnotes, abstract and bibliography) comprises approximately 7,467 words. 